\title{
44. CARBONATE SPIKES AND DISPLACED COMPONENTS AT DEEP SEA DRILLING PROJECT SITE 515: PLIOCENE/PLEISTOCENE DEPOSITIONAL PROCESSES IN THE SOUTHERN BRAZIL BASIN ${ }^{1}$
}

\author{
Alexander N. Shor and Glenn A. Jones, Lamont-Doherty Geological Observatory of Columbia University, \\ Palisades, New York \\ Kenneth A. Rasmussen, University of Rochester, Rochester, New York \\ and \\ Lloyd H. Burckle, Lamont-Doherty Geological Observatory of Columbia University, Palisades, New York
}

\begin{abstract}
Late Pliocene to Recent sediments from the southern Brazil Basin (DSDP Hole 515A, hydraulic piston core) were analyzed for evidence of episodic flow of Antarctic Bottom Water (AABW) through the Vema Channel. Carbonate-enriched layers punctuate the post-Pliocene section, otherwise composed predominantly of terrigenous silt and clay. Carbonate enrichment is thought to result from rapid deposition of fine-grained calcareous turbidites, originating in canyons incised on the northern margin of the Rio Grande Rise. The composition of benthic foraminiferal assemblages and the presence of stratigraphically displaced discoasters is consistent with a turbidite origin. Based on the presence of displaced Antarctic diatoms, AABW flow through the Vema Channel apparently has had a major influence on this site for only four periods during the last $2.7 \mathrm{Ma}$ (about 45 to $250 ; 375$ to $430 ; 700$ to $780 ; 1320$ to 1345 thousand yr. ago).
\end{abstract}

\section{INTRODUCTION}

Deep Sea Drilling Project (DSDP) Site 515 was located approximately $200 \mathrm{~km}$ north of the Vema Channel in the southern Brazil Basin (Fig. 1) to investigate the timing of flow events in Antarctic Bottom Water (AABW). The site was located atop a low-relief sedimentary high, interpreted to be a center of deposition for northward-transported clastic sediments (Site 515 chapter, this volume). The flow of AABW is inferred to slacken after passing through the constriction of the Vema Channel into the open basin. Site 515 is located within a field of sediment waves (Site 515 chapter, this volume), features which are commonly associated with moderate bottom currents (Heezen et al., 1959; Ewing et al., 1971; Hollister et al., 1974). The nature of the Quaternary sediment (principally nonbiogenic silt and clay), accumulating at rates in excess of $20 \mathrm{~m} / \mathrm{Ma}$ far from a terrestrial source and below the carbonate compensation depth (CCD), is consistent with the postulated current-transported origin. Scattered Antarcticsource diatoms confirm a distant southerly source for sediments in the uppermost levels as well as for three discrete intervals deeper in the section.

Hole 515A was cored at a water depth of $4252 \mathrm{~m}$. Previous studies of core top samples from this region have shown the carbonate lysocline to be at about $4050 \mathrm{~m}$, and the carbonate content of sediments from depths in excess of $4200 \mathrm{~m}$ to be negligible as a result of the increase in $\mathrm{CaCO}_{3}$ dissolution with depth (Melguen and Thiede, 1974; Johnson et al., 1977; Broecker and Takahashi, 1978). However, during routine analyses on

\footnotetext{
${ }^{1}$ Barker, P. F., Carlson, R. L., Johnson, D. A., et al., Init. Repts. DSDP, 72: Washington (U.S. Govt. Printing Office).
}

board the Glomar Challenger we noted that, although most of the Quaternary section had undetectable levels of carbonate $(<4 \%)$, a few intervals contained levels which occasionally exceeded $20 \%$ (Site 515 chapter, this volume). In addition, we observed Tertiary discoasters displaced into late Quaternary sediments. Although the "Karbonat Bombe" (Müller and Gastner, 1971) system on board provided only a crude estimate of absolute carbonate (reproducibility of only $\pm 4 \%$; Dunn, 1980), and our sample spacing was too coarse (about $50 \mathrm{~cm}$ intervals) to provide sufficient resolution, we speculated that carbonate preservation might be a cyclic response of the deep Brazil Basin to chemical changes in bottom water, in turn resulting from climatically controlled fluctuations in production of deep water around Antarctica (Barker et al., 1981). We were unable to correlate individual carbonate events with climatic cycles directly because of the paucity of fossils in the interbedded hemipelagic muds. Paleomagnetic measurements provided shipboard determinations of the Brunhes/Matuyama and Matuyama/Gauss magnetochron boundaries, however; and we observed that the frequency of the high $\mathrm{CaCO}_{3}$ intervals in the uppermost $50 \mathrm{~m}$ of Hole $515 \mathrm{~A}$ was roughly equivalent to that of the longest-period Milankovich cycle (about 100,000 yr.). We therefore defined a program of detailed measurement of $\mathrm{CaCO}_{3}$ for post-cruise study in the hope that more precise analytical techniques and more closely spaced sampling might provide clues to the nature of the processes which allowed $\mathrm{CaCO}_{3}$ to be preserved at this deep site.

\section{STRATIGRAPHY}

Core stratigraphy is based on the paleomagnetic polarity determinations of Hamilton (this volume). The Brunhes/Matuyama $(730,000$ years ago at $17.5 \mathrm{~m})$ and Matuyama/Gauss $(2,400,000$ years ago at $52.0 \mathrm{~m})$ bound- 


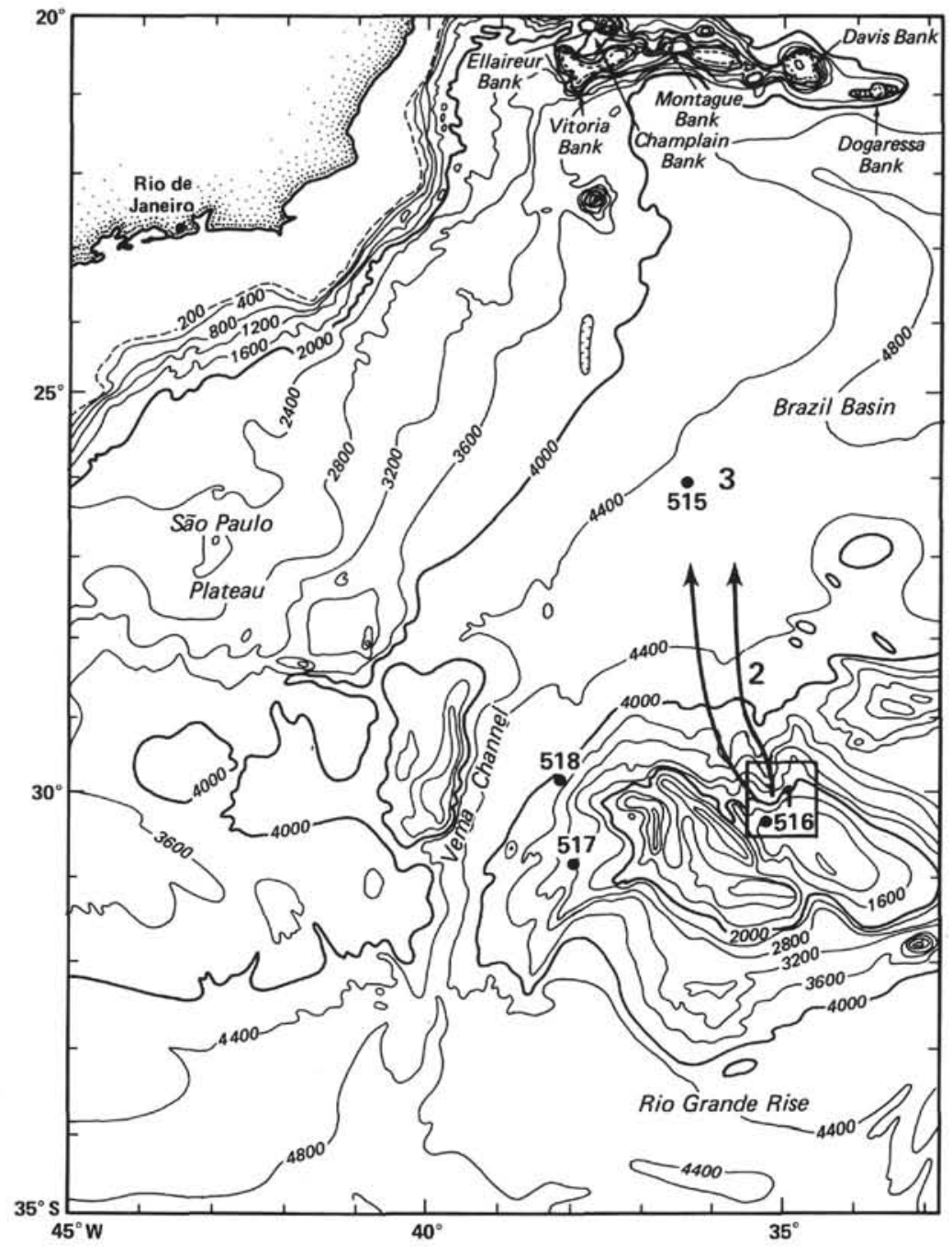

Figure 1. Bathymetry of southern Brazil Basin and Rio Grande Rise showing location of DSDP Site 515 . Site is located approximately $200 \mathrm{~km}$ north of Vema Channel, the principal conduit for northward-flowing Antarctic Bottom Water. Map shows relationship between canyon region and hiatuses on northern flank of Rio Grande Rise (2), proximal turbidites at the base of the Rio Grande Rise (1), and Hole 515A (3).

aries indicate an average accumulation rate of $22 \mathrm{~m} / \mathrm{Ma}$ over the $61 \mathrm{~m}$ examined. We have assumed that the core top represents an age of 0 , and have interpolated ages using $24 \mathrm{~m} / \mathrm{Ma}$ from 0 to $17.5 \mathrm{~m}$ and $21 \mathrm{~m} / \mathrm{Ma}$ below $17.5 \mathrm{~m}$. The paleomagnetic stratigraphy is confirmed by the diatom stratigraphy. We record the occurrence of Cosinodiscus elliptopora near the Jaramillo Event and the last occurrence of Actinocyclus ingens just after the Brunhes/Matuyama transition. Both of these diatoms are recorded in the same stratigraphic position in other Southern Ocean sediments (Donohue, 1970).

\section{$\mathrm{CaCO}_{3}$ ANALYSIS}

For the shore-based program we analyzed the top $61 \mathrm{~m}$ of DSDP hydraulic piston core (HPC) Hole $515 \mathrm{~A}$ at $10 \mathrm{~cm}$ intervals for $\mathrm{CaCO}_{3}$ on an instrument with a precision of $\pm 0.25 \%$. The gasometric technique used for this project was developed at Lamont-Doherty Geological Observatory in 1978, and has been in continuous use since then (Jones and Kaiteris, in press). An analysis is made in the following manner: $0.4 \mathrm{~g}$ of crushed $(<63 \mu \mathrm{m})$ and dried $\left(110^{\circ} \mathrm{C}\right)$ sediment and three $\mathrm{ml}$ of concentrated phosphoric acid are placed in separate com- partments of a reaction vessel, which is then evacuated, and the acid and sample are mixed. After $1 \frac{1}{2}$ hours of reaction time, the $\mathrm{CO}_{2}$ pressure is measured on a Curtin Matheson 63-5601 pressure manifold. The amount of $\mathrm{CaCO}_{3}$ in a sample is determined by a calibration curve of $\mathrm{mm} \mathrm{CO}_{2}$ pressure generated per $\mathrm{mg}$ of reagent grade $\mathrm{CaCO}_{3}$, after correcting for reaction vessel volume, temperature, atmospheric pressure, vapor pressure of the acid, and volume of nonreactive sediment. There are 36 reaction vessels, and one operator can analyze 36 samples in approximately five hours.

Of the 610 samples analyzed, 98 were rerun to check the reproducibility of the analyses. The quoted precision for this system is $\pm 0.25 \%$; thus the total difference between an analysis and its rerun should be less than $0.5 \%$ more than $68 \%$ of the time (Fig. 2).

\section{RESULTS}

The carbonate record of the upper $61 \mathrm{~m}$ of Hole $515 \mathrm{~A}$ is illustrated in Figure 3. The background $\mathrm{CaCO}_{3}$ concentration in these sediments is nil within the estimated $\pm 0.25 \%$ precision of analysis. Carbonate spikes punctuating the record are typically 40 to $80 \mathrm{~cm}$ thick, sharply peaked, and vary in amplitude from 0.7 to $30 \%$ $\mathrm{CaCO}_{3}$. 


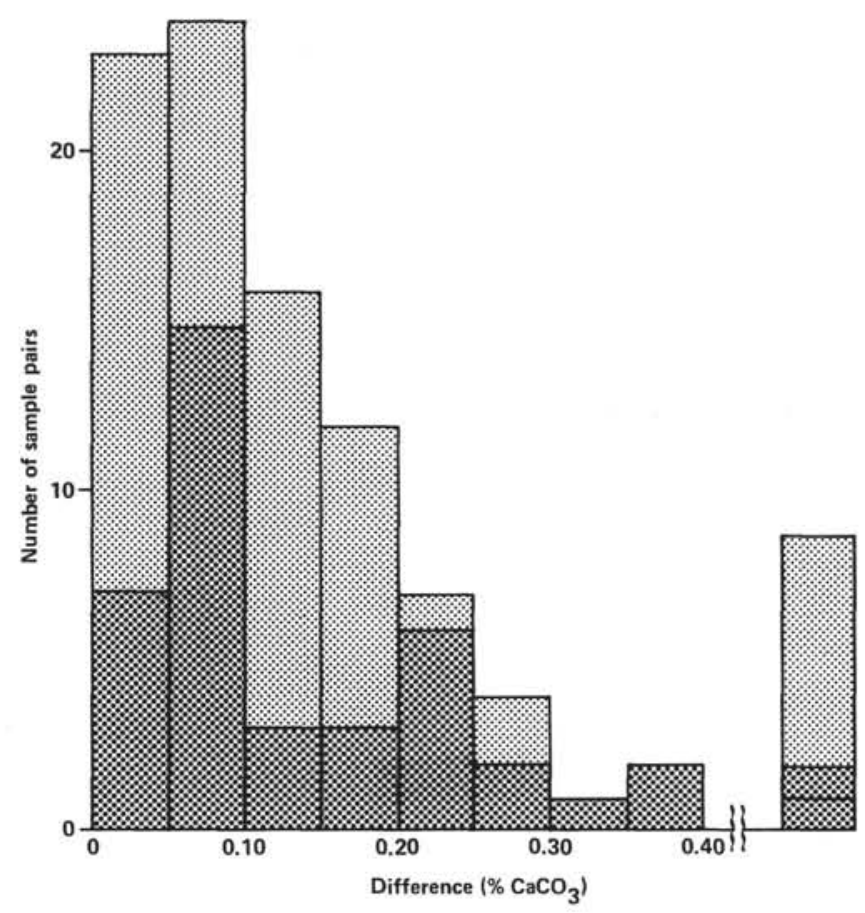

Figure 2. Histogram of 98 carbonate reruns, illustrating that $90 \%$ of analyses are reproducible to better than $0.4 \%$, and $76 \%$ to $0.2 \% \mathrm{CaCO}_{3}$. Heavily stippled boxes are samples from carbonate spikes ( $>0.4 \%$ total $\mathrm{CaCO}_{3}$ ); lightly stippled boxes are from background levels $\left(<0.4 \%\right.$ total $\left.\mathrm{CaCO}_{3}\right)$. Leaks in system result in high positive values. All single-point spikes were rerun to test for leaks. The two heavily stippled boxes in the $>0.4 \%$ column represent detected leaks.

The observed carbonate pattern confirms our initial speculation that carbonate-enriched layers punctuate the record as discrete spikes, and that this frequency is crudely similar to that of climatic oscillations (tens of thousands of years spacing). However, we do not observe a direct correspondence between carbonate content and specific isotopic stages of the Pleistocene which might indicate a direct link between carbonate deposition and climatic conditions.

The carbonate peaks show a striking similarity in shape to ash layer profiles (e.g., Ruddiman and Glover, 1972; Berger and Heath, 1968) in which "instantaneously" deposited laminae are vertically mixed throughout the sediments by benthic organisms. This suggests a mechanism for carbonate preservation unrelated to changes in AABW flow. We hypothesize that episodic turbidites originating on the Rio Grande Rise deposit thin layers of carbonate-rich sediments in the deep Brazil Basin in an environment below the carbonate compensation depth. Carbonate preservation is enhanced by the rapid rate of deposition of individual layers, as well as by burial of carbonate by burrowing organisms. This mechanism will be described more fully under Discussion.

The carbonate record of Site 515 contains variability in peak frequency and amplitude which may provide some clue to changes in depositional processes which have taken place through late Pliocene to Holocene time. The record may be roughly divided into three sec- tions of nominally equal duration: The uppermost $22 \mathrm{~m}$ of sediment (late Pleistocene) has carbonate "events" of variable amplitude and frequency; events in the middle $23 \mathrm{~m}$ (early Pleistocene) generally have high amplitudes and a more uniform frequency; and the lower $16 \mathrm{~m}$ (late Pliocene) almost totally lacks carbonate.

\section{CARBONATE COMPONENTS}

The principal calcareous components of the carbonate spikes are nannoflora, benthic and planktonic foraminifers, and unidentifiable fragments. Although the Last Abundance Datum (LAD) of discoasters is near the Plio/Pleistocene boundary (Ericson et al., 1964, McIntyre et al., 1967; Haq et al., 1977), discoasters are found in all but one of the carbonate spikes in Hole 515A (Table 1). The common occurrence of discoasters as well as other Miocene and Pliocene species in paleomagnetically dated upper Pleistocene sediments clearly indicates stratigraphic displacement.

Carbonate preservation is highly variable, and individual slides contain both highly dissolved and relatively well-preserved specimens. This contrast is particularly noticeable in discoasters. A single slide may contain both well-preserved specimens of Discoaster brouwerii (delicate features with no apparent dissolution) together with specimens of Discoaster variabilis exhibiting evidence of intense dissolution, as well as calcite overgrowths. The extreme variability of preservation and stratigraphic displacement argues strongly for a depositional process which has mixed fine-grained carbonate components from different stratigraphic levels and environments that exhibit varying degrees of carbonate preservation.

\section{BENTHIC FORAMINIFERAL ASSEMBLAGES}

An additional tool for understanding the origin of the $\mathrm{CaCO}_{3}$ spikes in Hole $515 \mathrm{~A}$ is the species composition of the benthic foraminifers found in the sediments containing these spikes. Numerous studies have shown that benthic foraminifers are valuable depth and water mass indicators (Bandy, 1953a; 1953b; Streeter, 1973; Schnitker, 1974; Pflum et al., 1976; Lohmann, 1978). Seven $\mathrm{CaCO}_{3}$ spikes were sampled for benthic foraminiferal species identification. Approximately 10 -g samples were sieved at $63 \mu \mathrm{m}$ and the coarse fraction was then dry sieved at $150 \mu \mathrm{m}$ and $250 \mu \mathrm{m}$. All benthic foraminifers were identified in both the $>250 \mu \mathrm{m}$ and 150 to $250 \mu \mathrm{m}$ size fraction (Table 2).

It was hoped that by performing a Q-mode principal components analysis on the benthic foraminiferal assemblages from the $\mathrm{CaCO}_{3}$ spikes in Hole $515 \mathrm{~A}$ and comparing the results to the Rio Grande Rise core top assemblages of Lohmann (1978), we would be able to estimate the source depth for the sediments comprising the $\mathrm{CaCO}_{3}$ spikes. Unfortunately, too few foraminifers are present for a quantitative analysis. Qualitatively, the benthic foraminiferal assemblages suggest that these sediments originate somewhat shallower than the depth of the site, consistent with the idea that these $\mathrm{CaCO}_{3}$ rich sediments are distal turbidites from the Rio Grande Rise. According to Lohmann (1978), benthic foraminif- 
A. N. SHOR, G. A. JONES, K. A. RASMUSSEN, L. H. BURCKLE

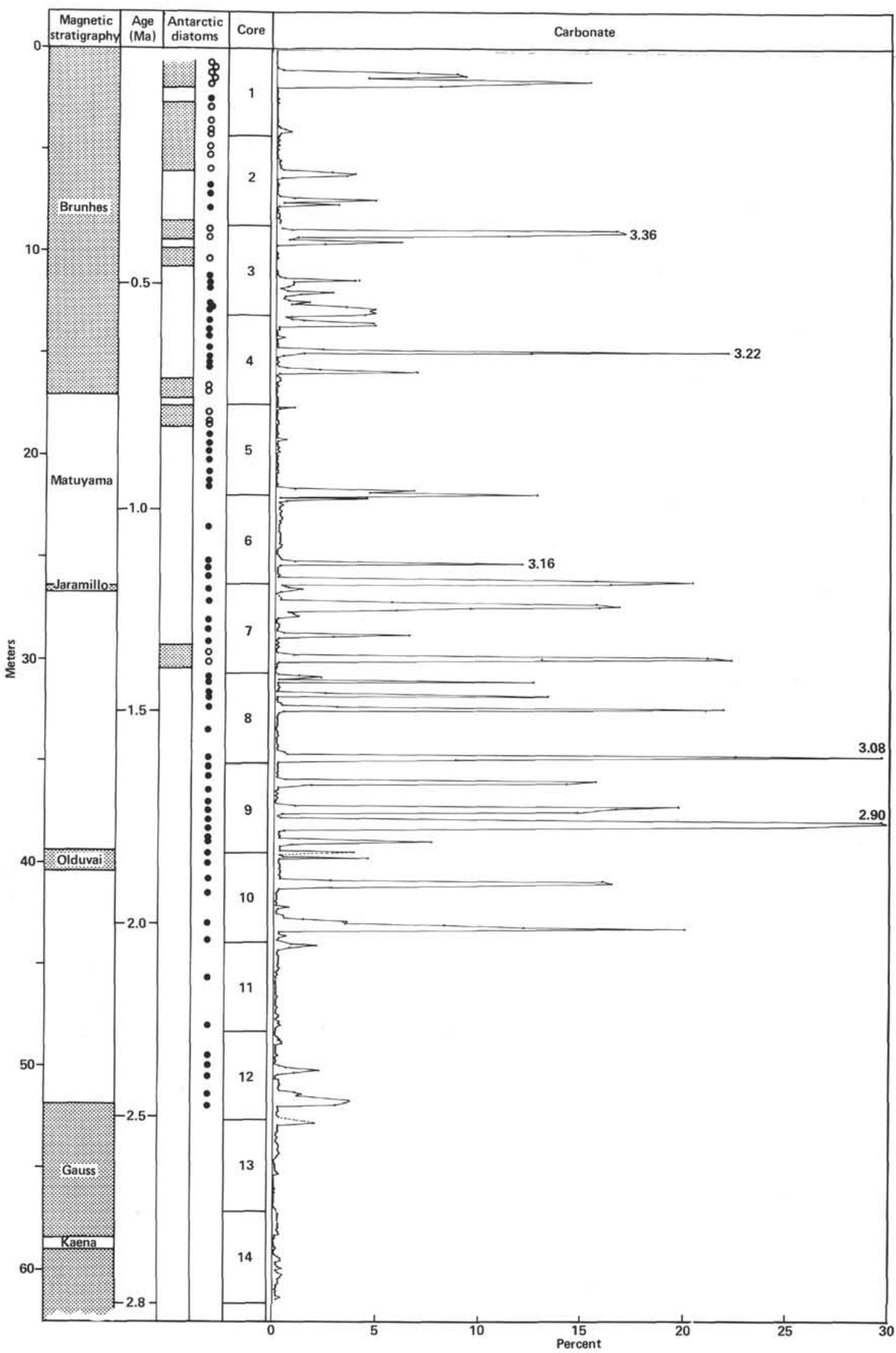

Figure 3. Carbonate determinations downcore are plotted together with presence/absence of displaced Antarctic-source diatoms and magnetic chronology boundaries used for stratigraphy (Hamilton, this volume). Open circles indicate presence of Antarctic-source diatoms at level shown; filled circles indicate samples examined in which diatoms were absent. Values of ${ }^{18} \mathrm{O}$ in 5 samples examined are shown adjacent to sample location at right (\%, relative to PDB). Core depths in meters below sediment surface; carbonate values in weight percent $\mathrm{CaCO}_{3}$. (See text for discussion.) 
Table 1. Displaced diatom and discoaster data, Hole 515A.

\begin{tabular}{|c|c|c|c|c|c|c|}
\hline $\begin{array}{l}\text { Core-section } \\
\text { (depth in section } \\
\text { in } \mathrm{cm} \text { ) }\end{array}$ & $\begin{array}{l}\text { Sub-bottom } \\
\text { depth (m) }\end{array}$ & $\begin{array}{l}\text { No. Antarctic } \\
\text { diatoms }\end{array}$ & $\begin{array}{l}\text { No. Antarctic } \\
\text { diatoms } / 8 \\
\left(\times 10^{4}\right)^{-}\end{array}$ & $\begin{array}{c}\mathrm{CaCO}_{3} \\
(\%)\end{array}$ & $\begin{array}{c}\text { No. } \\
\text { discoaster } \\
\text { species }\end{array}$ & $\begin{array}{l}\text { Additional levels } \\
\text { examined for } \\
\text { presence/absence }\end{array}$ \\
\hline $1-1,105$ & 1.05 & & & & & $\mathbf{P}$ \\
\hline $1-1,130$ & 1.30 & & & & & $\mathrm{P}$ \\
\hline $1-1,140$ & 1.40 & & & & & $\mathbf{P}$ \\
\hline $1-2,10$ & 1.60 & 17 & 9.8 & 15.3 & 5 & A \\
\hline $1-2,30$ & 1.80 & & & & & $\mathbf{P}$ \\
\hline $1-2,110$ & 2.60 & & & & & A \\
\hline $1-2,140$ & 2.90 & 4 & 1.4 & 0.0 & 0 & \\
\hline $1-3,60$ & 3.60 & & & & & $\mathbf{P}$ \\
\hline $1-3,104$ & 4.00 & & & & & A \\
\hline $1, C \mathrm{C}$ & 4.20 & & & & & A \\
\hline $2-1,60$ & 4.90 & 48 & 30.3 & 0.0 & 0 & \\
\hline $2-1,100$ & 5.30 & & & & & $\mathbf{P}$ \\
\hline $2-2,20$ & 6.00 & 1 & a & 0.0 & 4 & $\mathbf{P}$ \\
\hline $2-2,90$ & 6.70 & 1 & a & 0.0 & 0 & \\
\hline $2-2,100$ & 6.80 & & & & & A \\
\hline $2-2,149$ & 7.29 & 1 & a & 4.8 & 7 & A \\
\hline $2-3,70$ & 8.00 & 0 & 0 & 0.1 & 0 & \\
\hline $3-1,30$ & 9.00 & 8 & 1.2 & 17.0 & 10 & $\mathbf{P}$ \\
\hline $3-1,70$ & 9.40 & & & & & $\mathbf{P}$ \\
\hline $3-1,90$ & 9.60 & & & & & A \\
\hline $3-2,20$ & 10.40 & 4 & 1.6 & 0.0 & 0 & \\
\hline $3-2,110$ & 11.30 & 0 & 0 & 3.9 & 8 & A \\
\hline $3-2,149$ & 11.69 & 0 & 0 & 0.2 & 1 & \\
\hline $3-3,20$ & 11.90 & & & & & A \\
\hline $3-3,105$ & 12.75 & 0 & 0 & 4.7 & 10 & A \\
\hline $3-3,110$ & 12.80 & & & & & A \\
\hline $3, \mathrm{CC}$ & 13.05 & & & & & A \\
\hline $4-1,40$ & 13.50 & 0 & 0 & 4.8 & 8 & A \\
\hline $4-1,80$ & 13.90 & 0 & 0 & 0.1 & 0 & \\
\hline $4-1,110$ & 14.20 & & & & & A \\
\hline $4-2,20$ & 14.80 & 0 & 0 & 22.2 & 4 & tr. \\
\hline $4-2,70$ & 15.30 & 1 & a & 0.2 & 1 & 1 \\
\hline $4-2,100$ & 15.60 & & & & & A \\
\hline $4-2,120$ & 15.80 & 0 & 0 & 6.8 & 9 & \\
\hline $4-3,70$ & 16.80 & 18 & 3.5 & 0.1 & 0 & \\
\hline $4-3,100$ & 17.10 & & & & & $\mathbf{P}$ \\
\hline $4, \mathrm{CC}$ & 17.45 & & & & $\cdot$ & A \\
\hline $5-1,48$ & 17.98 & & & & & $\mathbf{P}$ \\
\hline $5-1,100$ & 18.50 & & & & & $\mathbf{P}$ \\
\hline $5-1,110$ & 18.60 & 45 & 25.1 & 0.1 & 0 & \\
\hline $5-2,140$ & 20.40 & 0 & 0 & 0.0 & 0 & \\
\hline $5-1,148$ & 18.98 & & & & & A \\
\hline $5, \mathrm{CC}$ & 21.70 & 0 & 0 & 12.7 & 4 & \\
\hline $5-2,45$ & 19.45 & & & & & A \\
\hline $5-2,97$ & 19.97 & & & & & A \\
\hline $5-2,148$ & 20.48 & & & & & A \\
\hline $5-3,50$ & 21.00 & & & & & A \\
\hline $5-3,100$ & 21.50 & & & & & A \\
\hline $6-2,20$ & 23.60 & 0 & 0 & 0.1 & 0 & \\
\hline $6-3,30$ & 25.20 & 0 & 0 & 12.0 & 4 & \\
\hline $6-3,70$ & 25.60 & 0 & 0 & 0.1 & 0 & \\
\hline $6-3,120$ & 26.10 & 0 & 0 & 20.4 & 4 & \\
\hline $7-1,40$ & 26.70 & 1 & $\mathrm{a}$ & 0.1 & 0 & \\
\hline $7-1,100$ & 27.30 & 0 & 0 & 16.8 & 5 & \\
\hline $7-2,40$ & 28.20 & 0 & 0 & 0.1 & 0 & \\
\hline $7-2,90$ & 28.70 & 0 & 0 & 6.5 & 6 & \\
\hline $7-2,140$ & 29.20 & 0 & 0 & 0.0 & 0 & \\
\hline $7-3,60$ & 29.90 & 45 & 29.5 & 22.3 & 4 & \\
\hline $7-3,110$ & 30.40 & 3 & 1.4 & 0.0 & 0 & \\
\hline $8-1,30$ & 31.00 & 0 & 0 & 12.8 & 2 & \\
\hline $8-1,60$ & 31.30 & 0 & 0 & 0.2 & 0 & \\
\hline $8-1,100$ & 31.70 & 0 & 0 & 13.4 & 0 & \\
\hline $8-1,130$ & 32.00 & 0 & 0 & 0.1 & 0 & \\
\hline $8-2,30$ & 32.50 & 0 & 0 & 23.0 & 1 & \\
\hline $8-2,149$ & 33.69 & 0 & 0 & 0.1 & 0 & \\
\hline $8-3,119$ & 34.89 & 0 & 0 & 29.6 & 1 & \\
\hline $9-1,30$ & 35.40 & 0 & 0 & 0.1 & 0 & \\
\hline $9-1,80$ & 35.90 & 0 & 0 & 0.0 & 0 & \\
\hline $9-1,149$ & 36.59 & 1 & a & 0.1 & 0 & \\
\hline $9-3,40$ & 38.50 & 0 & 0 & 0.2 & 0 & \\
\hline $9-3,80$ & 38.90 & 0 & 0 & 7.6 & 4 & \\
\hline $9-3,110$ & 39.20 & 0 & 0 & 0.3 & 0 & \\
\hline $10-1,20$ & 39.70 & 0 & 0 & 4.5 & 4 & \\
\hline $10-1,70$ & 40.20 & 0 & 0 & 0.2 & 0 & \\
\hline $10-1,149$ & 40.99 & 0 & 0 & 16.4 & 4 & \\
\hline $10-2,70$ & 41.70 & 0 & 0 & 0.1 & 0 & \\
\hline $10-3,70$ & 43.20 & 0 & 0 & 20.0 & 3 & \\
\hline $10-3,100$ & 43.50 & 0 & 0 & 0.6 & 0 & \\
\hline $11-1,10$ & 44.00 & 0 & 0 & 2.1 & 0 & \\
\hline $11-2,50$ & 45.90 & 0 & 0 & 0.1 & 0 & \\
\hline $11, \mathrm{CC}$ & 48.15 & 0 & 0 & 0.1 & 0 & \\
\hline $12-1,130$ & 49.60 & 0 & 0 & 0.1 & 0 & \\
\hline $12-3,30$ & 51.60 & 0 & 0 & 3.7 & 0 & \\
\hline $12-3,90$ & 52.20 & 0 & 0 & 0.1 & 0 & \\
\hline
\end{tabular}

Note: Samples indicated as P (present) or A (absent) were not counted, just examined for presence/absence.

a Values based on single specimens are not presented. 
Table 2. Benthic foraminifers, Hole 515A.

\begin{tabular}{|c|c|c|c|c|c|c|c|c|c|c|c|c|}
\hline $\begin{array}{l}\text { Core-section } \\
\text { (level in } \mathrm{cm} \text { ) }\end{array}$ & $\begin{array}{c}\text { Epistominella } \\
\text { umbonifera }\end{array}$ & $\begin{array}{c}\text { Oridorsalis } \\
\text { tener }\end{array}$ & Fissurina & $\begin{array}{l}\text { Cibicidoides } \\
\text { kullenbergi }\end{array}$ & Pyrgo & $\begin{array}{l}\text { Quinquil- } \\
\text { oculina }\end{array}$ & $\begin{array}{l}\text { Uvigerina } \\
\text { peregrina }\end{array}$ & $\begin{array}{l}\text { Pullenia } \\
\text { bulloides }\end{array}$ & $\begin{array}{c}\text { Melonis } \\
\text { pompilioides }\end{array}$ & $\begin{array}{c}\text { Epistominella } \\
\text { exigua }\end{array}$ & $\begin{array}{l}\text { Unident } \\
\text { or other }\end{array}$ & $\begin{array}{l}\delta^{18} \mathrm{O} \text { and } \delta^{13} \mathrm{C} \\
\text { (PDB Standard) }\end{array}$ \\
\hline $3-1,30$ & 11 & 2 & 0 & 2 & 0 & 0 & 1 & 0 & 0 & 4 & 2 Unident & $\begin{array}{l}+3.36 \pm 0.02 \\
+0.14 \pm 0.02\end{array}$ \\
\hline $4-2,20$ & 13 & 6 & 0 & 0 & 1 & 0 & 0 & 0 & 3 & 5 & 0 & $\begin{array}{l}+3.22 \pm 0.04 \\
+0.13 \pm 0.01\end{array}$ \\
\hline $6-3,30$ & 14 & 8 & 1 & 7 & 1 & 0 & 2 & 1 & 0 & 3 & $\begin{array}{l}1 \text { Lagena } \\
\text { nebulosa }\end{array}$ & $\begin{array}{c}+3.16 \pm 0.05 \\
0.00 \pm 0.02\end{array}$ \\
\hline $7-3,60$ & 0 & 4 & 0 & 3 & 2 & $1 ?$ & 0 & 0 & 3 & 5 & 0 & - \\
\hline $8-3,120$ & 8 & 12 & 1 & 6 & 2 & 0 & 1 & 0 & 0 & 6 & 0 & $\begin{array}{l}+3.08 \pm 0.05 \\
+0.15 \pm 0.03\end{array}$ \\
\hline $9-2,140$ & 8 & 0 & 1 & 2 & 0 & 0 & 0 & 0 & 1 & 5 & $\begin{array}{l}3 \text { Lagena } \\
\text { nebulosa } \\
1 \text { Dentalina } \\
1 \text { Gyrodina } \\
2 \text { Unident }\end{array}$ & $\begin{array}{l}+2.90 \pm 0.07 \\
+0.34 \pm 0.03\end{array}$ \\
\hline $10-3,70$ & 0 & 0 & 0 & 1 & 0 & 0 & 0 & 0 & 0 & 1 & 0 & - \\
\hline
\end{tabular}

Note: Dashes indicate that there were too few specimens for isotopic analysis.

eral assemblages from core tops near the depth of the site (4252 $\mathrm{m}$ ) are essentially monospecific (Epistominella umbonifera), in contrast to the mixed assemblages observed in Site 515 samples (Table 2).

Stable isotopic analyses were performed on the benthic foraminifers $E$. umbonifera in an attempt to understand the climatic timing (i.e., glacial or interglacial) and/or source of the $\mathrm{CaCO}_{3}$-rich deposits. Samples were analyzed for both $\delta^{18} \mathrm{O}$ and $\delta^{13} \mathrm{C}$ at Woods Hole Oceanographic Institution on a Model 602E V.G. Micromass using a preparation similar to Keigwin's (1979) technique. At least six specimens were run from each sample to provide sufficient material for analysis. Two of the seven samples examined contained too few $E$. umbonifera specimens for an analysis.

Most published isotopic records of benthic foraminifers are referenced to Uvigerina peregrina. For direct comparison, E. umbonifera isotopic values are corrected by $+0.46 \%$ (Graham et al., 1981). Glacial to interglacial changes in $\delta^{18} \mathrm{O}$ approach $2 \%$ for benthic samples, with interglacial values of $U$. peregrina $\sim+3.0 \%$ and glacial values $\sim+5.0 \%$ (Ninkovich and Shackleton, 1975; Streeter and Shackleton, 1979; Ruddiman and McIntyre, 1981a). The measured $\delta^{18} \mathrm{O}$ values of $E$. umbonifera (and the comparable values for $U$. peregrina) are shown in Figure 4.

All five samples examined for $\delta^{18} \mathrm{O}$ exhibit values which are intermediate between full glacial and interglacial values (biased towards interglacial) with a total range observed of less than $20 \%$ of the full glacial to interglacial range of $2 \%$. The results are ambiguous for stratigraphic purposes, suggesting that the $\mathrm{CaCO}_{3}$ spikes are composed of a mixture of reworked glacial and interglacial age sediment. However, it is also possible that the samples examined represent an intermediate climatic regime.

\section{DISPLACED ANTARCTIC-SOURCE DIATOMS}

Sixty smear slides were quantitatively examined for the Antarctic diatom species Nitzschia kerguelensis, Coscinodiscus lentiginosus, C. tabularis, Eucampia antarctica, Asteromphalus parvulus, Hemidiscus karstenii, and Charcotia actinochilus, which have been used successfully as tracers of AABW in previous studies in the South Atlantic (Burckle and Stanton, 1975). Rarely were

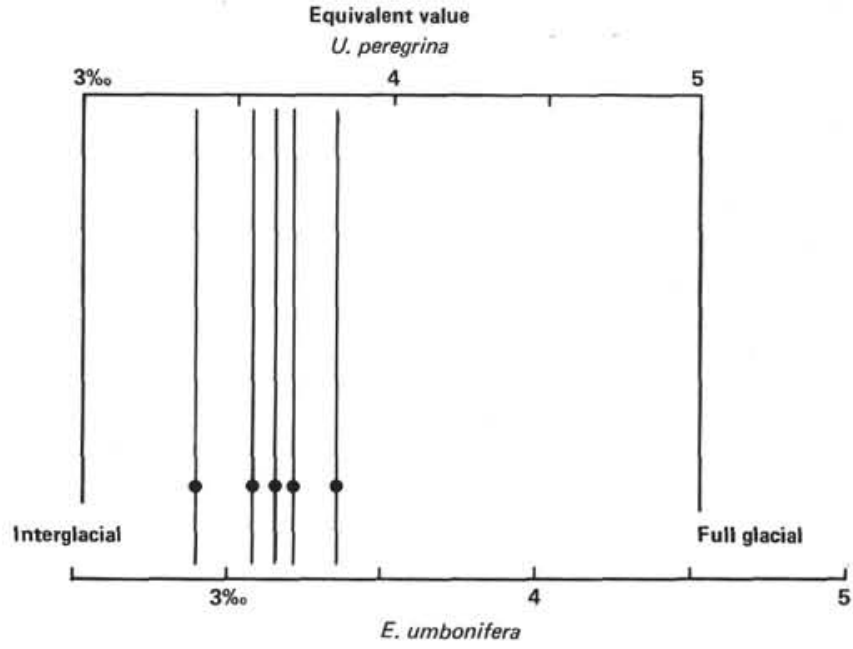

Figure 4. Plot of ${ }^{18} \mathrm{O}$ (vs. PDB) for five samples of $E$. umbonifera from carbonate spikes (Table 2) $\left({ }^{18} \mathrm{O}\right.$ in \%). Equivalent values of ${ }^{18} \mathrm{O}$ for $U$. peregrina and total glacial-interglacial range are shown (see text for discussion).

all species found on a single slide. Most slides were dominantly composed of $N$. kerguelensis and C. lentiginosus. To allow for calculation of the number of specimens per gram of sediment, slides were prepared according to the technique of Burckle and Stanton (1975). At least one slide was examined from each carbonate peak and interpeak zone between 1.6 and $52.2 \mathrm{~m}$ subbottom. An additional 35 slides were examined qualitatively for presence/absence of diatoms. All results are listed in Table 1. Diatom specimens are found in varying states of preservation and fragmentation.

Only four stratigraphic intervals (nine slides) contained significant numbers of displaced diatoms (in excess of $10^{4}$ specimens per $\mathrm{g}$ ). These levels are 1.1 to $6.0 \mathrm{~m}$ (about 45 to 250 thousand yr. ago), 9.0 to $10.4 \mathrm{~m}$ (about 375 to 430 thousand yr. ago), 16.8 to $18.6 \mathrm{~m}$ (about 700 to 780 thousand yr. ago), and 29.9 to $30.4 \mathrm{~m}$ (about 1320 to 1345 thousand yr. ago). An additional six slides contained a single diatom each, equivalent to 2 to $6 \times 10^{3}$ specimens per g. Observations of single specimens are not considered significant. Stratigraphic constraints are not sufficient to define a correspondence between diatom deposition and climatic regime (e.g., oxy- 
gen isotope stages). However, it is quite clear from these data that no simple correlation exists between presence or absence of displaced Antarctic diatoms and the carbonate record (Fig. 5). We interpret this negative evidence to indicate that separate processes are responsible for deposition of carbonate and diatoms at the site.

\section{DISCUSSION}

We believe that the anomalously high $\mathrm{CaCO}_{3}$ spikes found in HPC Hole 515A are fine-grained, distal turbidites originating from the Rio Grande Rise. As such, Hole $515 \mathrm{~A}$ is a valuable key in understanding the history, frequency, and possible mechanisms of sediment remobilization in this region. A number of observations have led us to the distal turbidite explanation. First, one would expect the $\mathrm{CaCO}_{3}$ content of these sediments to be essentially zero, based upon the depth of Hole 515A and the depth of the modern CCD, yet some spikes are in excess of $20 \% \mathrm{CaCO}_{3}$. Deposition of sediment from a turbidite is a geologically instantaneous event. Rapid deposition should help to preserve $\mathrm{CaCO}_{3}$ since the processes of bioturbation would mix and bury these $\mathrm{CaCO}_{3}$ rich sediments, protecting at least some of these sediments from the corrosive bottom waters found at this depth.

Can we demonstrate that these events are really instantaneously deposited $\mathrm{CaCO}_{3}$-rich sediments that have been bioturbated? Numerous studies have used the instantaneously deposited tracers, volcanic ash, and microtektites to study the processes of bioturbation in

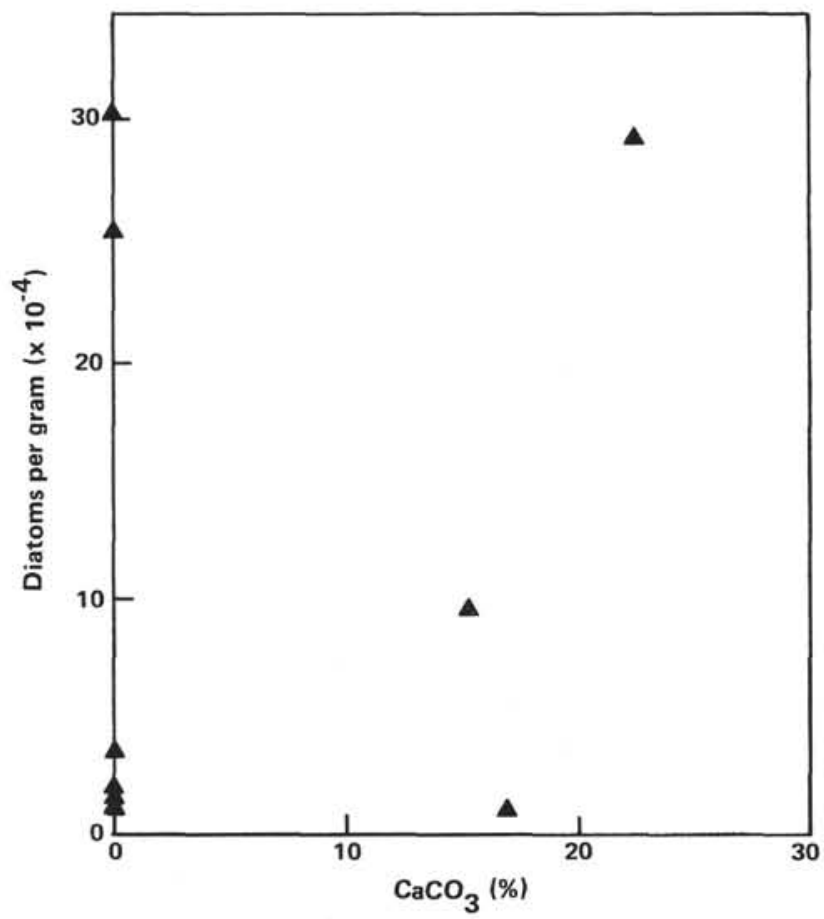

Figure 5. Plot of percent carbonate vs. per gram abundances of displaced diatoms for nine samples with significant numbers of Antarctic-source diatoms. No correlation is observed, suggesting different processes control $\mathrm{CaCO}_{3}$ and diatom deposition. The additional 48 samples examined for diatoms, which contain 0 or 1 diatom each, plot along the $\mathrm{CaCO}_{3}$ axis. deep-sea sediments (Glass, 1969; Ruddiman and Glover, 1972; Ruddiman et al., 1980). By knowing the input function (i.e., instantaneously deposited event) and measuring the tracer distribution in the sediment after it has been bioturbated, one can derive models of the benthic mixing process. Measured profiles of bioturbated volcanic ash zones from deep-sea sediments exhibit distinctive and characteristic profiles that differ from bioturbated climatic signals, which change on time scales of thousands of years (Ruddiman et al., 1980; Ruddiman and McIntyre, 1981b). To test this hypothesis a representative $\mathrm{CaCO}_{3}$ spike centered at $5.55 \mathrm{~m}$ sub-bottom $(2-2,25 \mathrm{~cm})$ was sampled at $2.5 \mathrm{~cm}$ intervals. This profile was then compared to the distribution of a representative volcanic ash (Ash Zone 1 in Core K708-1 of Ruddiman and Glover, 1972). As can be seen from Figure 6 there is excellent agreement between the two profiles, suggesting similar post-depositional processes. Ruddiman and Glover (1972) estimated the total thickness of volcanic ash at the time of deposition to have been 0.14 $\mathrm{cm}$ in Core $\mathrm{K} 708-1$. Using a similar argument we infer the initial thickness of the $\mathrm{CaCO}_{3}$ event in Hole $515 \mathrm{~A}$ (HPC) to be of the order $0.2 \mathrm{~cm}$ to no more than $1.0 \mathrm{~cm}$. Four additional spikes analyzed at $2.5 \mathrm{~cm}$ intervals reveal similar inferred thicknesses, leading us to assume that all of the spikes recorded in the $61 \mathrm{~m}$ analyzed were of initial thickness less than $1.0 \mathrm{~cm}$ and initial $\mathrm{CaCO}_{3}$ contents about $90 \%$.

The second reason for proposing the distal turbidite mechanism is the presence of proximal turbidites in the southernmost Brazil Basin and well-developed canyon systems on the north flanks of the Rio Grande Rise. Four cores collected in the summer of 1980 from the base of the Rio Grande Rise in the southernmost Brazil Basin ( 4250 to $4400 \mathrm{~m}$ ) contain $\mathrm{CaCO}_{3}$-rich turbidites. These sediments are clearly graded, and each event ranges in thickness from 10 to more than $400 \mathrm{~cm}$. All of these turbidites contain reworked sediment (Johnson et al., 1982). Although Hole 515A is approximately $200 \mathrm{~m}$ shallower than the base of the northern flank of the Rio Grande Rise, we believe these two areas are related as regions of distal and proximal turbidite deposition. Evidence for upslope flows of turbidity currents has been reported from Lake Zurich (Kelts and Hsü, 1980), the Ceara Rise (Damuth and Embley, 1979), and the Nares Abyssal Plain (Abbott, pers. comm., 1982).

Johnson and Peters (1979) defined a region of welldeveloped canyon systems and hiatuses between depths of about 2000 to $3500 \mathrm{~m}$ on the northern flanks of the Rio Grande Rise. This canyon system appears to be the most likely source of the reworked sediments collected from the base of the Rio Grande Rise and the $\mathrm{CaCO}_{3}$ spikes at Hole 515A. Figure 1 shows our interpretation of the interrelationship of these three regions. More detailed analyses will allow a clearer understanding of sediment remobilization and deposition in this region.

The third line of evidence is the examination of displaced components from Hole 515A. There is no correlation (positive or negative) between the presence of displaced Antarctic diatoms, which have been shown to be excellent tracers of AABW (Johnson et al., 1977), and 

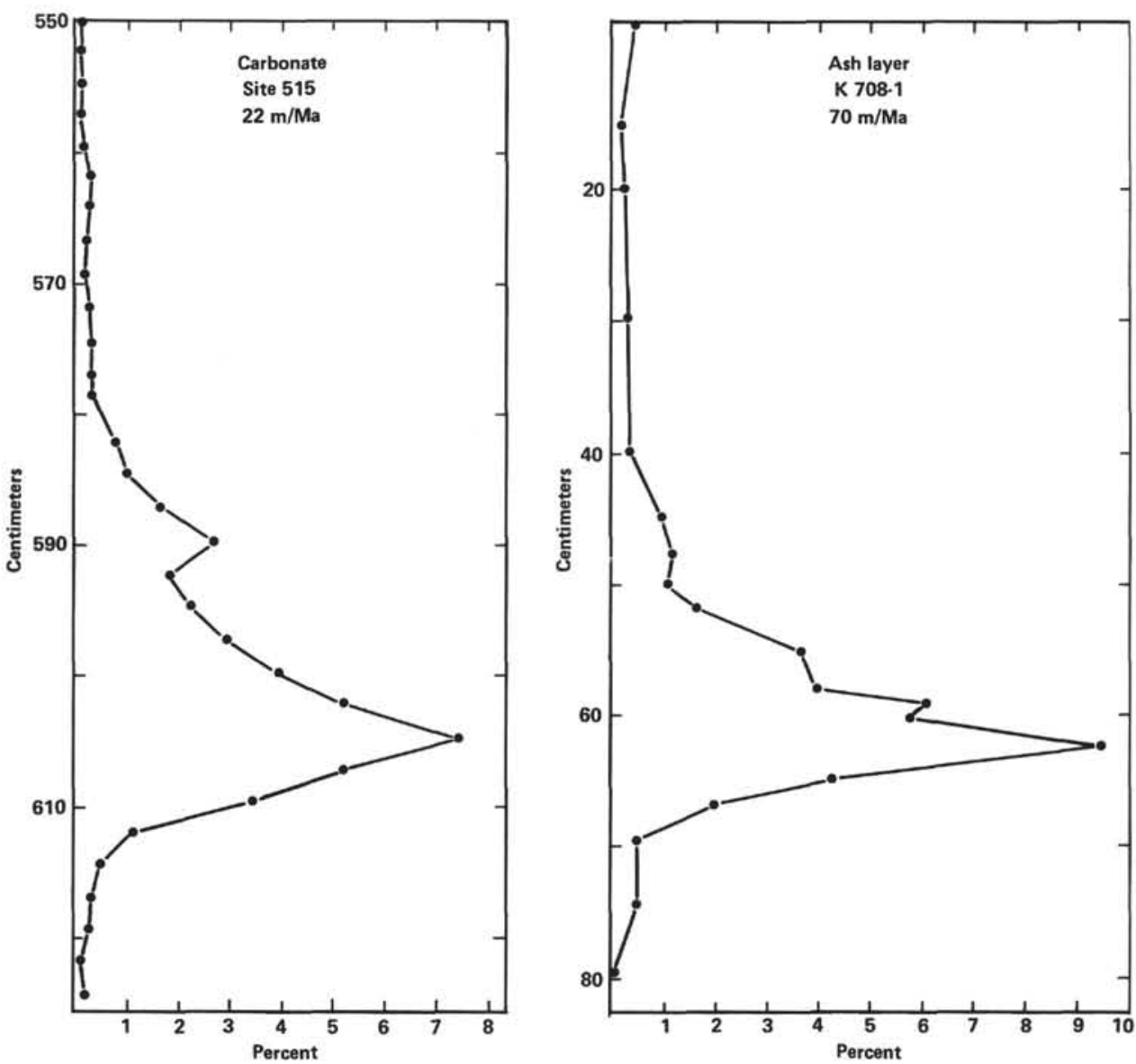

Figure 6. Comparison of a typical carbonate event from Hole 515A with a representative dispersed volcanic ash profile of Ash Zone 1 from the North Atlantic (Ruddiman and Glover, 1972). Similarity of these two records suggest $\mathrm{CaCO}_{3}$ events in Hole 515A are bioturbated instantaneously deposited events.

the $\mathrm{CaCO}_{3}$-rich peaks. Essentially all of the $\mathrm{CaCO}_{3}$ spikes contain displaced discoasters (Table 1), and the benthic foraminiferal assemblages (Table 2) suggest an origin of these sediments from shallower than $4000 \mathrm{~m}$ and probably from within the canyon region identified by Johnson and Peters (1979) on the northern flank of Rio Grande Rise.

Although we believe the mechanism of $\mathrm{CaCO}_{3}$ spike formation in Hole 515A (HPC) to be downslope transport of material from the Rio Grande Rise, there are two alternative explanations that deserve attention.

First, the present-day lysocline and CCD in the Rio Grande Rise region are about $4050 \mathrm{~m}$ and $4200 \mathrm{~m}$, respectively (Melguen and Thiede, 1974). If these levels had fluctuated by only 100 to $200 \mathrm{~m}$, alternate preservation and nonpreservation of $\mathrm{CaCO}_{3}$ should result, and could possibly explain the record we see in Hole 515A. Backtracking of DSDP sites has shown that the CCD has fluctuated a number of times during the Cenozoic, with some changes in excess of $1 \mathrm{~km}$ (e.g., Berger, 1973; Berger and Winterer, 1974). These data demonstrate changes over periods of hundreds of thousands of years, while the data from Hole 515A require essentially instantaneous changes. Berger (1977) has presented data covering the last 20,000 years that suggest the Aragonite Compensation Depth (ACD) fluctuated by as much as
$1 \mathrm{~km}$ in only 2,000 years. These dramatic changes occurred during a period of rapid climatic change centered at about 14,000 to 12,000 years ago. It is therefore possible that the $\mathrm{CaCO}_{3}$ record of Hole $515 \mathrm{~A}$ is climatically induced and that the sediments from these spikes are not redeposited. This explanation, however, does not account for the presence of displaced components in all $\mathrm{CaCO}_{3}$ spikes.

The second alternative explanation is that of lateral advection of sediments to the site by bottom currents, more specifically northward-flowing Antarctic Bottom Water. One of the main objectives for coring Hole 515A was to obtain a record of AABW history from the Eocene/Oligocene boundary to the present. The exact location is on what appears to be a depositional mound some $200 \mathrm{~km}$ north of the northern terminus of the Vema Channel. Initially the spiky $\mathrm{CaCO}_{3}$ record was thought to reflect changes in the intensity of $\mathrm{AABW}$ flow over the site, with less $\mathrm{CaCO}_{3}$ indicative of more intense AABW production (more dissolution). One of the best and easiest AABW indicators to measure is the presence/absence or abundance change of displaced Antarctic diatoms (Johnson et al., 1977). Although there are clear changes in the distribution of displaced Antarctic diatoms within Hole $515 \mathrm{~A}$, there is no obvious positive or negative correlation with the $\mathrm{CaCO}_{3}$ spikes 
(Fig. 5). We can therefore be reasonably certain that changes in the flow of AABW are not solely responsible for the observed $\mathrm{CaCO}_{3}$ record.

The sedimentation history of Hole 515A includes deposition of a normal pelagic component, a laterally advected AABW component, and a downslope turbidite component. A number of independent sets of data support the distal turbidite origin of the $\mathrm{CaCO}_{3}$ spikes in Hole $515 \mathrm{~A}$. The spikes have concentration profiles similar to known instantaneously deposited components which have been bioturbated; all spikes contain reworked discoasters; the benthic foraminiferal composition suggests an origin shallower than $4000 \mathrm{~m}$; and there appears to be a connection between the canyon systems of the northern Rio Grande Rise (Johnson and Peters, 1979), the proximal turbidites at the base of the Rio Grande Rise, and Site 515.

\section{ACKNOWLEDGMENTS}

Dave Johnson, Eben Franks, Bill Curry, and Lloyd Keigwin of Woods Hole Oceanographic Institution provided supervision of benthic foraminiferal identification and isotopic analyses. The manuscript was reviewed by D. Johnson, A. McIntyre, R. Flood, and D. Lazarus. This study was carried out in the absence of specific funding. A. Shor is grateful to the Deep Sea Drilling Project for allowing him to participate in Leg 72 of Glomar Challenger. Lamont-Doherty Geological Observatory Contribution No. 3506.

\section{REFERENCES}

Bandy, O. L., 1953a. Ecology and paleoecology of some California foraminifera. Part I. The frequency distribution of recent Foraminifera off California. J. Paleontol, 27:161-182. 1953b. Ecology and paleoecology of some California foraminifera. Part II. Foraminiferal evidence of subsidence rates in the Ventura Basin. J. Paleontol., 27:200-203.

Barker, P. F., Carlson, R. L., Johnson, D. A., and Shipboard Scientific Party, 1981. Deep Sea Drilling Project Leg 72: Southwest Atlantic paleocirculation and Rio Grande rise tectonics. Geol. Soc. Am. Bull., 92:294-304.

Berger, W. H., 1973. Cenozoic sedimentation in the Eastern Tropical Pacific. Geol. Soc. Am. Bull., 84:1941-1954.

1977. Deep-sea carbonate and the deglaciation preservation spike in pteropods and Foraminifera. Nature, 269:301-304.

Berger, W. H., and Heath, G. R., 1968. Vertical mixing in pelagic sediments. J. Mar. Res., 26:134-142.

Berger, W. H., and Winterer, E. L., 1974. Plate stratigraphy and the fluctuating carbonate line. In Hsü, K. J., and Jenkyns, H. C. (Eds.), Pelagic Sediments on Land and Under the Sea. Int. Assoc. Sedimentol. Spec. Publ. 1:11-48.

Broecker, W. S., and Takahashi, T., 1978. The relationship between lysocline depth and in situ carbonate ion concentration. Deep-Sea Res., 25:65-95.

Burckle, L. H., and Stanton, D., 1975. Distribution of displaced Antarctic diatoms in the Argentine Basin. Diatom Symposium Volume, Diatom Conference (Kiel, F.R.G.), pp. 283-291.

Damuth, J. E., and Embley, R. W., 1979. Upslope flow of turbidity currents on the northwest flanks of the Ceara Rise: Western Equatorial Atlantic. Sedimentology, 26:825-834.

Donohue, J. G., 1970. Pleistocene diatoms as climatic indicators in North Pacific sediments. Mem. Geol. Soc. Am. 126:121-138.

Dunn, D. A., 1980. Revised techniques for quantitative calcium carbonate analysis using the "Karbonat Bombe", and comparisons to other quantitative carbonate analysis methods. J. Sediment. Petrol., 50:631-637.

Ericson, D. B., Ewing, M., and Wollin, G., 1964. The Pleistocene epoch in deep-sea sediments. Science, 146:723-732.

Ewing, M., Eittreim, S. L., Ewing, J. I., and LePichon, X., 1971. Sediment transport and distribution in the Argentine Basin. 3. Nepheloid layer and processes of sedimentation. Physics and Chemistry of the Earth (Vol. 8), pp. 48-77.
Glass, B. P., 1969. Reworking of deep-sea sediments as indicated by the vertical dispersion of the Australian and Ivory Coast microtektite horizons. Earth Planet. Sci. Lett., 6:409-415.

Graham, D. W., Corliss, B. H., Bender, M. L., and Keigwin, L. D., Jr., 1981. Carbon and oxygen isotopic disequilibria of recent deepsea benthic foraminifera. Mar. Micropaleontol., 6:483-498.

Haq, B. U., Berggren, W. A., and Van Couvering, J. A., 1977. Corrected age of the Plio/Pleistocene boundary. Nature, 269:483-489.

Heezen, B. C., Tharp, M., and Ewing, M., 1959. The floors of the oceans-I. The North Atlantic. Geol. Soc. Am. Spec. Pap., 65.

Hollister, C. D., Flood, R. D., Johnson, D. A., Lonsdale, P. F., and Southard, J. B., 1974. Abyssal furrows and hyperbolic echo traces on the Bahama Outer Ridge. Geology, 2:395-400.

Johnson, D. A., Ledbetter, M., and Burckle, L. H., 1977. Vema Channel paleooceanography: Pleistocene dissolution cycles and episodic bottom water flow. Mar. Geol., 23:1-33.

Johnson, D. A., and Peters, C. S., 1979. Late Cenozoic sedimentation and erosion on the Rio Grande Rise. J. Geol., 87:371-392.

Johnson, D. A., Rasmussen, K., and Jones, G., 1982. Late Pleistocene deposition of bioclastic turbidites and contourites in the Brazil Basin. EOS, Trans. A. Geophys. Union, 63:361.

Jones, G. A., and Kaiteris, P., in press. A vacuum-gasometric technique for rapid and precise analysis of calcium carbonate in sediments and soils. J. Sediment. Petrol.

Keigwin, L. D., 1979. Late Cenozoic stable isotope stratigraphy and paleooceanography of DSDP sites from the east equatorial and central north Pacific Ocean. Earth Planet. Sci. Lett., 45:361-383.

Kelts, K., and Hsü, K. J., 1980. Resedimented facies of 1875 Horgen slumps in Lake Zurich and a process model of longitudinal transport of turbidity currents. Eclogae Geol. Helv., 73:271-281.

Lohmann, G. P., 1978. Abyssal benthonic Foraminifera as hydrographic indicators in the western South Atlantic Ocean. J. Foraminiferal Res., 8:6-34.

McIntyre, A., Bé, A. W. H., and Priekstas, R., 1967. Coccoliths and the Pliocene-Pleistocene boundary. Prog. Oceanog., 4:3-25.

Melguen, M., and Thiede, J., 1974. Facies distribution and dissolution depths of surface sediment components from the Vema Channel and the Rio Grande Rise (southwest Atlantic Ocean). Mar. Geol., 17:341-353.

Müller, G., and Gastner, M., 1971. The "Karbonat Bombe," a simple device for the determination of the carbonate content in sediments, soils, and other materials. N. Jahrb. Mineral. Mh., 10: 466-469.

Ninkovich, D., and Shackleton, N. J., 1975. Distribution, stratigraphic position and age of ash layer "L," in the Panama Basin region. Earth Planet. Sci. Lett., 27:20-34.

Pflum, C. E., and Frerichs, W. E., 1976. Gulf of Mexico deep-water foraminifera. Cushman Found. Foraminiferal Res., Spec. Publ., 14.

Ruddiman, W. F., and Glover, L. K., 1972. Vertical mixing of icerafted volcanic ash in North Atlantic sediments. Geol. Soc. Am. Bull., 83:2817-2836.

Ruddiman, W. F., Jones, G. A., Peng, T.-H., Glover, L. K., Glass, B. P., and Liebertz, P. J., 1980. Tests for size and shape dependency in deep-sea mixing. Sediment. Geol., 25:257-276.

Ruddiman, W. F., and McIntyre, A., 1981a. Oceanic mechanisms for amplification of the 23,000-year ice-volume cycle. Science, 212: 617-627.

1981b. The North Atlantic Ocean during the last deglaciation. Palaeogeog., Palaeoclimatol., Palaeoecol., 35:145-214.

Ruddiman, W. F., Molfino, B., Esmay, A., and Pokras, E., 1980. Evidence bearing on the mechanism of rapid deglaciation. Clim. Change, 3:65-87.

Schnitker, D., 1974. West Atlantic abyssal circulation during the past 120,000 years. Nature, 248:385-387.

Streeter, S. S., 1973. Bottom water and benthonic Foraminifera in the North Atlantic-Glacial-interglacial contrasts. Quat. Res., 3: 131-141.

Streeter, S. S., and Shackleton, N. J., 1979. Paleocirculation of the deep North Atlantic: 150,000 year record of benthic Foraminifera and oxygen-18. Science, 203:168-171.

Date of Initial Receipt: July 9, 1982 